\section{Evaluation of trypanocidal activity from Calea uniflora (Heliantheae-Asteraceae) extracts}

\author{
Andréa Mendes do Nascimento ${ }^{1}$; Dionéia C. R. de Oliveira ${ }^{1 *}$; \\ Sérgio Albuquerque ${ }^{2 *}$
}

${ }^{1}$ Departamento de Física e Química

2 Departamento de Ciências da Saúde

Faculdade de Ciências Farmacêuticas de Ribeirão Preto, Universidade de São Paulo, Avenida do Café s/n, 14040-903, Ribeirão Preto, SP, Brazil

sdalbuq@fcfrp.usp.br / drolivei@fcfrp.usp.br

\begin{abstract}
Dichloromethane crude extract from xylopodium of Calea uniflora Less (Heliantheae-Asteraceae) showed in vitro trypanocidal activity against trypomastigote forms of Trypanosoma cruzi. The data obtained allow to conclude that the crude extract must be investigate to identify its active compounds.
\end{abstract}

American trypanosomiasis (Chagas' disease) is a severe disease that occurs in Latin America. It is caused by flagellate protozoan Trypanosoma cruzi, transmitted by triatomine insects and by blood transfusion. To develop strategies for keeping the vector insect population and to prevent infection by blood transfusion are two ways for controlling the disease $^{1}$. Gentian violet is the only chemoprophylatic agent employed for this purpose. Although it may cause undesirable effects in the patients ${ }^{2}$. New chemicals for use in banked blood or drugs for treatment of acute and chronic infections are urgently required ${ }^{3}$. Plant extracts may be potential sources of such compounds. Calea uniflora Less is a plant belonging to the tribe Heliantheae, family Asteraceae. The genus contains about 110 species and are found in Mexico, Central and South America ${ }^{4}$. It is important to note that some species of the genus Calea are used for stomach disease ${ }^{5,6,7,8}$. Cerain et al. ${ }^{9}$ observed cytotoxic activity of Calea glomerata extract. In this work we report the results of the evaluation of the in vitro trypanocidal activity of Calea uniflora extracts. The trypanocidal bioassay are shown in Table 1 and by the results we belive that the dichloromethane extract of xylopodium have compounds with

Table 1. In vitro trypanocidal activity of crude extracts from Calea uniflora

\begin{tabular}{l|l}
\hline Crude extracts & \% lysis $\pm(\mathrm{SD})$ \\
\hline Aerial parts in $\mathrm{CH}_{2} \mathrm{Cl}_{2}$ & $41.73 \pm 2.73$ \\
\hline Aerial parts in ethanol & $19.67 \pm 14.75$ \\
\hline Xylopodium in $\mathrm{CH}_{2} \mathrm{Cl}_{2}$ & $98.81 \pm 1.18$ \\
\hline Xylopodium in ethanol & $37.00 \pm 19.67$ \\
\hline
\end{tabular}

Rev. Bras. Farmacogn., v. 12, supl., p. 49-50, 2002.

ISSN: 0102-695X high trypanocidal activity.

\section{Material and Methods}

Plant material: Calea uniflora Less. was collected at the Washington Luis highway, $1 \mathrm{~km}$ far from Posto Castelo, on March, 1997. Plant identification was performed by Dr. Jose L. Panero from Department of Botany, University of Texas, USA, and a voucher specimen (SPFR 04003) is deposited in the herbarium of Department of Biology, FFCLRP/USP.

Extraction procedures: Dried and powdered aerial parts (63 g) were exhaustively extracted with $\mathrm{CH}_{2} \mathrm{Cl}_{2}$ and ethanol at room temperature affording 0.127 and $3.38 \mathrm{~g}$ of crude extracts respectively. Dried and powdered xylopodium $(200 \mathrm{~g})$ also were extracted with $\mathrm{CH}_{2} \mathrm{Cl}_{2}$ and ethanol 4.24 and $9.65 \mathrm{~g}$ of crude extracts respectively.

Bioassay with trypomastigotes: All the extracts were submitted to in vitro biological assay against trypomastigotes blood forms of T. cruzi. The bioassays were carried out usin blood collected by cardiac puncture of Swiss albino mice in the parasitemy peak (seventh day) after infection with the Y strain of T. cruzi. The blood was diluted with not infected murine blood to give a concentration of ca. $2 \times 10^{6}$ trypomastigote forms $/ \mathrm{ml}$. Stock solutions of the extracts to be tested were prepared by dissolution in DMSO (dimethyl sulfoxide) to a final concentration of $25 \mathrm{mg} / \mathrm{ml}$. The bioassays were performed in triplicate on microtitre plates ( 96 wells) which contained $200 \mathrm{ml}$ of mixture/well. To each sample, aliquots of the stock solutions were added to the diluted blood in such quantities as to give final concentrations of $4,0 \mathrm{mg} / \mathrm{ml}$ sample per $\mathrm{mL}$ of mixture in the wells. The plates were incubated at $4{ }^{\circ} \mathrm{C}$ during $24 \mathrm{~h}$ and the number of parasites determined according to Brener ${ }^{10}$. Controls were blood of infected mice without any addition, infected blood containing DMSO in equivalent amounts as the samples, and infected blood containing gentian violet (positive control) at a concentrations of $250 \mathrm{mg} / \mathrm{ml}$.

\section{Acknowledgements}

The authors are grateful to Fundação de Amparo a Pesquisa do Estado de São Paulo (FAPESP) for financial support.

\section{References}

${ }^{1}$ Bastos JK, Albuquerque S, Silva MLA. Evaluation of the trypanocidal activity of lignans isolated from the leaves of Zanthoxylum naranjillo. Planta Medica 1999; 65: 541-4

${ }^{2}$ Ribeiro A, Piló-Veloso D, Romanha AJ, Zani CL. Trypanocidal flavonoids from Trixis vauthieri. J. Nat. Prod. 1997; 60: 836-8. ${ }^{3}$ Santos AF, Ferraz PAL, Abreu FC, Chiari E, Goulart MOF, Sant'ana AEG. Molluscicidal and trypanocidal activities of lapachol derivatives. Planta Medica 2001; 67: 92-3

${ }^{4}$ Karis PO, Ryding O. Tribe Heliantheae. In: Bremer K. 
Asteraceae: cladistics and classification. Timber Press, Inc., Portland, 1994: 559-624

${ }^{5}$ Martinez M, Esquivel B, Ortega A. Two caleines from Calea zacatechichi. Phytochemistry 1987; 26: 2104-6

${ }^{6}$ Steinbeck C, Spitzer V, Starosta M, Poser G. Identification of two chromenes from Calea serrata by semiautomatic structure elucidation. J. Nat. Prod. 1997; 60: 627-8

${ }^{7}$ Kato ETM, Akisue MK, Matos FJA, Craveiro AA, Alecar JM. Constituents of Calea pinnatifida. Fitoterapia 1994; 65: 377

${ }^{8}$ Ferreira ZS, Roque NF, Gottlieb OR, Oliveira F. Compostas medicinais do Brasil. Estudo químico da Calea pinatifida. Cienc. Cult. 1980; Suppl 32: 83-5

${ }^{9}$ Cerain AL, Pinzón R, Calle J, Marín A, Monge A. Cytotoxic activities of colombian plant extracts on chinese hamster lung fibroblasts. Phytotherapy Research 1996; 10: 431-2

${ }^{10}$ Brener Z. Therapeutic activity and criterion of cure on mice experimentally infected with Trypanosoma cruzi. Rev. Inst. Med. Trop. 1962; 4: 389-96

\section{Evaluation of the central activity of the ethanolic extract of Acosmium subelegans (Mohlenbr) in mice}

\author{
Ricardo A. Vieira'; Antonio J. Lapa; Thereza C. M. de Lima ${ }^{\text {* }}$ \\ 1 Laboratory of Neuropharmacology, Department of \\ Pharmacology, CCB, Universidade Federal de Santa Catarina, \\ 88015-420, Florianópolis, SC \\ ${ }^{2}$ Natural Products Section, Department of Pharmacology, \\ Escola Paulista de Medicina, UNIFESP, 04044-020, São Paulo, \\ SP, Brazil \\ thereza@farmaco.ufsc.br
}

\begin{abstract}
The ethanolic extract (EE) of Acosmium subelegans (Mohlenbr) Yakovl (perobinha-do-campo) was tested to behavioral paradigms in mice to investigate its putative central depressant effect. Oral pretreatment with the EE significantly reduced in a dose-dependent way the locomotor activity and increased by $30-55 \%$ the barbiturate sleep duration relatively to control values. At the highest dose $\left(1,0 \mathrm{~g} \cdot \mathrm{kg}^{-1}\right)$ it decreased the extension time/flexion time ratio of the maximal electroshockinduced convulsions, enhanced the latency to the pentylenetetrazol-induced convulsions and diminished by $26 \%$ the number of seizures, indicating an anticonvulsant action. No changes were observed in the motor coordination, the core temperature, climbing behavior, catalepsy and the plus-maze performance. The preliminary results indicate that the EE of A. subelegans induce a CNS depressant effect, more specifically an anticonvulsant effect that deserve a thorough investigation.
\end{abstract}

Acosmium subelegans (Mohlenbr) Yakovl, Leguminaceae, popularly known as "perobinha-do-campo", is used in the Brazilian folk medicine as sedative or "tranquilizer", in epilepsy treatmenr, in hysteria, nervous breakdown and chorea $^{1}$. Previous pharmacological studies described that the benzenic extracts obtained from the related species Acosmium dasycarpum (Vog) Yakovl produced a depressant effect upon the central nervous system (CNS) of rats and mice, revealed by a potentiation of barbiturate-sleep, a reduction of the spontaneous and the amphetamine-induced locomotor activity. No protection against pentylenetetrazol and stricnine-induced convulsions was seen ${ }^{2}$. The extract main active constituent was identified as lupeol, a triterpene compound. Lupeol, also reduced the ambulation of mice and potentiated the barbiturate-hypnosis without affecting the animals motor coordination ${ }^{3}$. Comparatively, the ethanolic extract of A. subelegans presented a similar profile of action, decreasing the locomotion in rats ${ }^{4}$ and potentiating the barbiturate-induced sleep in mice ${ }^{5}$. The present 